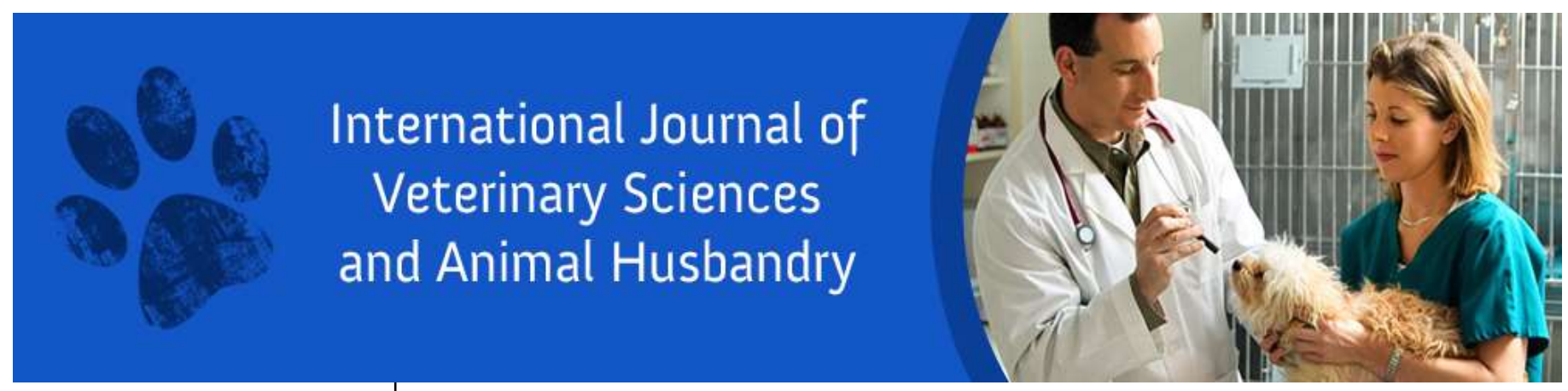

ISSN: $2456-2912$

VET 2021; 6(1): 19-22

(C) $2021 \mathrm{VET}$

www.veterinarypaper.com

Received: 13-11-2020

Accepted: 15-12-2020

Dr. Vinu M Nampoothiri

Veterinary Surgeon, Veterinary

Dispensary, Morayur,

Malappuram, Kerala, India

\section{Ghrelin and its role in animals}

\section{Dr. Vinu M Nampoothiri}

DOI: $\underline{\text { https://doi.org/10.22271/veterinary.2021.v6.i1a.318 }}$

\section{Abstract}

Ghrelin is a 28-amino acid peptide hormone secreated mainly from stomach in animals. Ghrelin stimulate release of growth hormone. Ghrelin works with the help of ghrelin receptors. Ghrelins main function is to increase hunger and regulate feed intake. Ghrelin performs other functions like stimulation of gastric acid secreation, helps in the regulation of carbohydrate metabolism, increase body fat content, corticosteroid release, reproductive functions and metabolic adaptation of lactation also. All these functions of ghrelin are discussed in detail in this article.

Keywords: Ghrelin, hormone, receptor, feed

\section{Introduction}

The word ghrelin can be actually split up into two i.e. "Ghre" which means grow and "Relin" which means hormone. Ghrelin is a 28 -amino acid peptide modified at its third residue, a serine (Ser3), by a middle-chain fatty acid, n- octanoic acid (Ueno et al., 2005) ${ }^{[29]}$. Ghrelin was discovered by Kojima in $1999^{[10]}$. Ghrelin has been found in fishes, amphibians, birds, and many mammals. Ghrelin is secreated from fundic part of the stomach. Ghrelin is primarily expressed in the X/A- like cells of the oxyntic gland in the stomach of monogastrics and the abomasum of ruminant animals (Date et al., 2000) ${ }^{[3]}$. There are lower levels expressed in the small intestine, the pancreas, lymphocytes, placenta, kidney, lung, brain, pituitary and gonads (Barreiro and Tena-Sempere, 2004) ${ }^{[2]}$. Growth hormone release from the anterior pituatary is under the control of two hormones growth hormone releasing hormone and somatostatin from hypothalamus. But later found that some opiod peptide derivatives had weak growth hormone releasing activity. It was found that small synthetic peptidyl and non-peptidyl molecules called growth-hormone secretagogues (GHSs) have growth hormone releasing action (Smith et al., 1997). Release of growth hormone by GHS is through GHS receptors (GHS-R). The GHS-R exists in two isoforms, $1 \mathrm{a}$ and $1 \mathrm{~b}$, the former of which is the functional receptor for ghrelin (Kojima et al., 1999) ${ }^{[10]}$. GHSs and ghrelin stimulate GH release by increasing intracellular $\mathrm{Ca}^{2+}$ levels through the activation of the phospholipase-IP3 pathway.

Ghrelin increase hunger through its action on hypothalamic feeding centers. Ghrelin occurs in 2 forms

a) n- octanylated/ acylated (AG)

b) des acylated (DAG)

The main function of AG is GH secreation and function of DAG is lipogenesis.

\section{Ghrelin Receptors}

Ghrelin receptors are of two types, one is centrally placed one and the other one is peripherally placed one. Receptors were located in hypothalamus, pituitary, hippocampus, liver as well as vagal afferent endings throughout the GI tract. Ghrelin is the only identified endogenous ligand for GHS-R (Growth Hormone Secretogogue Receptor). GHS-R is concentrated in the pituitary cells where ghrelin promotes GH releasing activities (Lorenzi et al., 2009) ${ }^{[14]}$. GHSR had two subtypes - GHS-R1a \& GHS-R1b (Barreiro and Tena-Sempere, 2004) ${ }^{[2]}$. GHS-R1a expressed in negative energy balance (Litwack et al., 2008) ${ }^{[13]}$. Ghrelin acts on the lateral nucleus (Hunger/feeding center) and stimulate appetite. Ghrelin acts on the arcuate nucleus to regulate appetite.
Corresponding Author:
Dr. Vinu M Nampoothiri Veterinary Surgeon, Veterinary Dispensary, Morayur, Malappuram, Kerala, India 


\section{Ghrelin and regulation of feed intake}

Ghrelin is a strong orexigenic and adipogenic molecule (Nakazato et al., 2001) ${ }^{[18]}$. Hypothalamus and GI tract are closely linked in the regulation of feed intake. Fos protein is a protein seen in areas where the ghrelin receptor is distributed. It was found that expressing antisense ghrelin receptor mRNA decreases $\mathrm{GH}$ secreation, food intake and body fat mass in transgenic rats (Shuto et al., 2002) ${ }^{[23]}$. Ghrelins orexigenic activity is independent of GH signaling pathway (Nakazato et al., 2001) ${ }^{[18]}$. Continuous intra cerebro ventricular (ICV) administration of ghrelin induces food intake and an increase in fat mass, leading to weight gain (Tschop, 2000) ${ }^{[28]}$. Neuropeptide Y (NPY) and agouti related protein (AgRP) are the ghrelin responsive orixigenic peptides in the hypothalamic arcuate nucleus (ARC). ICV administration of ghrelin shown to induce Fos expression in 39\% of NPY/AgRP-expressing neurons and increase both NPY and AgRP mRNA levels in ARC (Seoane et al., 2003) ${ }^{[22]}$.

Circulating ghrelin levels are increased by fasting and decreased by feeding in rats (Toshinai et al., 2001) ${ }^{\text {[27]. In }}$ addition, hyperglycemia reduces circulating ghrelin levels (Nakagawa et al., 2002) ${ }^{[17]}$. These reports suggest that ghrelin has a role in the regulation of appetite. In sheep on programmed feeding regimens, the pre-prandial increase in plasma ghrelin levels (and the rise with pseudo-feeding) is followed by a rise in plasma GH levels (Sugino et al., 2002) ${ }^{[25]}$, strongly suggesting that the former stimulates the latter. Wertz et al., (2004) ${ }^{[30]}$ compared the plasma ghrelin level of fast and fed steer and he noticed that the plasma level of ghrelin on fed steer was lower than that of fast steer. Miura $e t$ al., (2014) ${ }^{[15]}$ studied the effect of feeding on ghrelin level in cows and found higher level of ghrelin in plasma during fasting time and $4 \mathrm{hrs}$ after feeding compared to one hr after feeding.

Salfen et al., (2004) ${ }^{[21]}$ found that exogenous ghrelin has a variety of endocrine effects and shows potential in increasing body weight gain in pigs during weaning. If ghrelin can decrease the length of weaning anorexia and increase body weight gain during the weaning period, pigs will potentially be able to better resist pathological and environmental challenges during this time. But in contrary Wu et al., (2008) ${ }^{[32]}$ found that exogenous ghrelin at the dosage of $1 \mu \mathrm{g} / \mathrm{d}$ pig could cause a variety of behavioral effects, but not improve performance of weanling piglets.

\section{Ghrelin and other gastrointestinal effects}

Intravenous administration of ghrelin to rats stimulates gastric acid secretion and gastric motility (Kamegai et al., 2001) ${ }^{[8]}$. Ghrelin affects gastric function through vagus nerve (Ueno et al., 2005) ${ }^{[29]}$. Ghrelin protect against ethanol induced gastric ulcers in rat (via nitric oxide dependent central mechanism) (Sibilia et al., 2003) ${ }^{[24]}$. Chicken ghrelin caused contractile responses in smooth muscle strips isolated from various parts of the GI tract (Kitazawa et al., 2007) ${ }^{[9]}$. Ghrelin causes gastric contraction in japanese quail (Kitazawa et al., 2009) ${ }^{[9]}$. But in rabbits ghrelin does not induce contraction (Peeters et al., 2005) ${ }^{[19]}$.

\section{Ghrelin and carbohydrate metabolism}

Ghrelin increases circulating glucose levels via GH release, increasing insulin resistance and stimulating gluconeogenesis (Muller et al., 2001) ${ }^{[16]}$. Ghrelin stimulate Insulin Receptor Substrate 1 (IRS1) as well as its downstream signaling molecules. It inhibits Akt activation and opposed effect of insulin on rate-limiting enzyme of gluconeogenesis, phosphoenolpyruvate carboxykinase, therefore upregulating gluconeogenesis (Korbonits et al., 2004) ${ }^{[11]}$. Krueger and Melendez (2012) ${ }^{[12]}$ observed lower concentrations of serum insulin on ghrelin (5 microgram $/ \mathrm{kg}$ body weight intramuscularly) treated group compared to the untreated group.

\section{Ghrelin and adipose tissue}

The chronic ghrelin administration has been shown to increase body fat content in rodents (Tschop, 2000) ${ }^{[28]}$. Ghrelin treated animals do not increase their weight but increase their fat tissue content as assessed by MRI (Wren et al., 2004) [31]. Ghrelin increases levels of PPAR gamma mRNA, which stimulates differentiation of preadipocytes in vitro. According to Thompson et al., (2004) [26] ghrelin infused to bone marrow improved bone marrow fat cell proliferation.

\section{Ghrelin and corticosterone releasing activity}

Ghrelin stimulates the corticosteroid release in humans, pigs, cows, mice and rats. Ghrelin receptors are present in adrenal gland (Rucinski et al., 2009) ${ }^{[20]}$. Azzam et al., (2017) ${ }^{[1]}$ found that hypothalamic pituitary adrenal (HPA) axis mediated elevations in ghrelin plasma concentration require increased peripheral cortisol levels, independent of central elevation of adreno cortico tropic hormone (ACTH) and possibly corticotropin releasing hormone $(\mathrm{CRH})$ levels and concluded that further studies are needed to elucidate whether a neuroendocrine feedback system between the HPA axis and ghrelin secretion exists.

Table 1: Comparison of ghrelin effect across vertebrates

\begin{tabular}{|c|c|c|c|c|}
\hline Effect & Mammals & Aves & Amphibians & Fishes \\
\hline GH release & Stimulate & Stimulate & Stimulate & Stimulate \\
\hline Corticosteroids release & Stimulate & Stimulate & Stimulate & Stimulate \\
\hline Feeding & Stimulate & Inhibit & - & Stimulate \\
\hline Plasma level during fasting & Increase & Increase & Increase & Increase \\
\hline GI contraction & contraction & contraction & - & No effect \\
\hline Drinking & Inhibit & Inhibit & No effect & Inhibit \\
\hline
\end{tabular}

(Modified from Kaiya et al., 2013) ${ }^{[7]}$.

\section{Ghrelin and Reproduction}

Ghrelin expression is high during diestrus time (Barreiro and Tena-Sempere, 2004) ${ }^{[2]}$. Diestrus is the period of corpus luteum formation. Ghrelin expression was located in the ruptured follicle, the corpus luteum (CL) (Barrerio and TenaSempere, 2004).CL produces progesterone. So from this it can be assumed that ghrelin and progesterone had a parallel production pattern with regard to reproductive system. Ghrelin expression is higher during the beginning of gestation and also acts to maintain the pregnancy (Garcia et al., 2007) [5].

\section{Ghrelin in metabolic adaptation of lactation}

Ghrelin is also involved in the control of prolactin secretion, which stimulates milk production (Barreiro and TenaSempere, 2004) ${ }^{[2]}$. Ghrelin causes an increase in food intake, increase digestion and absorption. This results in an increased propionate and amino acid absorption from gut. Ghrelin helps in the mobilization of tissue reserves during lactation. Ghrelin also increases lipoprotein lipase activity in the mammary gland (Felix, 2010) ${ }^{[4]}$. when ghrelin levels were increased, milk production also increased which then caused the weight of the offspring to also increase (Gottero et al., 2004) ${ }^{[6]}$. Felix (2010) ${ }^{[4]}$ found that high producing cows $(12,923 \pm 217 \mathrm{~kg}$ of milk) had lower levels of plasma ghrelin $(45.1 \pm 8.9 \mathrm{pg} / \mathrm{ml})$ 
compared to the low producing cows $(10,332 \pm 322 \mathrm{~kg}$ of milk; $73.3 \pm 8.5 \mathrm{pg} / \mathrm{ml}$ of ghrelin), but the high producers produced more milk in comparison to the low producers and he concluded that although the results were the opposite of what we anticipated, they may be the result of prioritized nutrient partitioning in an attempt to maintain a favorable energy status.

\section{Conclusion}

Ghrelin is a recently discovered endogenous peptide that participate in energy homeostasis by stimulating $\mathrm{GH}$ secretion. Ghrelin controls feeding behavior. Ghrelin is an ultimate anabolic hormone. Along with its above mentioned effects ghrelin found to have effects on the cardiovascular system, sympathetic system etc. But only little information is available about its physiology and function.

\section{References}

1. Azzam I, Gilad S, Limor R, Stern N, Greenman Y. Ghrelin stimulation by hypothalamic pituitary adrenal axis activation depends on increasing cortisol levels. Endocrine Connections 2017;6:847-855.

2. Barreiro ML, Tena-Sempere M. Ghrelin and reproduction: A novel signal linking energy status and fertility? Molecular \& Cellular Endocrinology 2004;226(1-2):1-9.

3. Date Y, Kojima M, Hosoda H, Sawaguchi A, Mondal MS, Suganuma $\mathrm{T}$, et al. Ghrelin, a novel growth hormone-releasing acylated peptide, is synthesized in a distinct endocrine cell type in the gastrointestinal tracts of rats and humans. Endocrinology 2000;141(11):42554261.

4. Felix EM. Circulating ghrelin concentrations during the transition period of dairy cattle and the associated relationship with milk production. Thesis submitted to the Honors college, University of Arizona 2010.

5. Garcia MC, Lopez M, Alvarez CV, Casanueva F, TenaSempere M, Dieguez C. Role of ghrelin in reproduction. Reproduction 2007;133(3):531-540.

6. Gottero C, Broglio F, Prodam F, Destefanis S, Bellone S, Benso A, et al. Ghrelin: A link between eating disorders, obesity and reproduction. Nutr. Neurosci 2004;7(56):255-270.

7. Kaiya H, Kangawa K, Miyazato M. What is the general action of ghrelin for vertebrates?-Comparisons of ghrelin's effects across vertebrates. Gen. Comp. Endocrin 2013, 187-191.

8. Kamegai J, Tamura H, Shimizu T, Ishii S, Sugihara H. and Oikawa S. Regulation of the ghrelin gene: growth hormonereleasing hormone upregulates ghrelin mRNA in the pituitary, Endocrinology 2001;142:4154-4157.

9. Kitazawa T, Kaiya H, Taneike T. Contractile effects of ghrelin related peptides on the chicken gastrointestinal tract in vitro. Peptides 2007;28(3):617-24.

10. Kojima M, Hosoda H, Date Y, Nakazato M, Matsuo H, Kangawa $\mathrm{K}$, et al. Ghrelin is a growth-hormone-releasing acylated peptide from stomach. Nature 1999;402:656-60.

11. Korbonits M, Gueorguiev M, Grady EO, Lecoeur C, Swan DC, Mein CA, et al. A variation in the ghrelin gene increases weight and decreases insulin secretion in tall, obese children, J. Clin. Endocrinol. Metab 2002;87:40054008.

12. Krueger T, Melendez P. Effect of ghrelin on feed intake and metabolites in lambs. Appetite 2012;58(2):758-759.
13. Litwack G, Begley T, Means A, O'Malley B, Riddiford L, Tashjian JA, et al. Ghrelin. Oxford, UK, Elsevier Inc 2008.

14. Lorenzi T, Meli R, Marzioni D, Morroni M, Baragli A, Castellucci M, et al. Ghrelin: A metabolic signal affecting the reproductive system. Cytokine Growth Factor Rev 2009;20(2):137-152.

15. Miura H, Hojo N, Takahashi R, Kikuchi M. The influence of feeding pattern on changes in plasma ghrelin in the Holstein cow.J Vet. Med. Sci 2014;76(8).

16. Muller AF, Janssen JA, Hofland LJ, Lamberts SW, Bidlingmaier M, Strasburger CJ, et al. Blockade of the growth hormone $(\mathrm{GH})$ receptor unmasks rapid $\mathrm{GH}$ releasing peptide-6-mediated tissue-specific insulin resistance, J. Clin. Endocrinol. Metab 2001;86:590-593.

17. Nakagawa E, Nagaya N, Okumura H, Enomoto M, Oya $\mathrm{H}$, Ono F, et al. Hyperglycaemia suppresses the secretion of ghrelin, a novel growth-hormone-releasing peptide: responses to the intravenous and oral administration of glucose. Clin. Sci. (Lon) 2002;103:325-328.

18. Nakazato M, Murakami N, Date Y, Kojima K, Matsuo H, Kangawa $\mathrm{K}$, et al. A role for ghrelin in the central regulation of feeding. Nature 2001;409:194-8.

19. Peeters TL. Ghrelin: A new player in the control of gastrointestinal functions. Gut 2005;54(11):1638-1649.

20. Rucinski M, Ziolkowska A, Tyczewska M, Malendowicz LK. Expression of prepro ghrelin and related receptor genes in the rat adrenal gland and evidences that ghrelin exerts a potent stimulating effect on corticosterone secretion. Peptides 2009;30(8):1448-1455.

21. Salfen BE, Carroll JA, Keisler DH, Strauch TA. Effects of exogenous ghrelin on feed intake, weight gain, behavior, and endocrine responses in weanling pigs. J. Anim. Sci 2004;82:1957-1966.

22. Seoane LM, Lopez M, Tovar S, Casanueva FF, Senaris $\mathrm{R}$, Dieguez $\mathrm{C}$, et al. Agouti-related peptide, Y. neuropeptide, and somatostatin-producing neurons are targets for ghrelin actions in the rat hypothalamus. Endocrinology 2003;144:544-51

23. Shuto Y, Shibasaki T, Otagiri A, Kuriyama H, Ohata H, Tamura $\mathrm{H}$, et al. Hypothalamic growth hormone secretagogue receptor regulates growth hormone secretion, feeding, and adiposity. J Clin Invest 2002;109:1429-36.

24. Sibilia V, Rindi G, Pagani F, Rapetti D, Locatelli V, Torsello A, et al. Ghrelin protects against ethanol induced gastric ulcers in rats: studies on the mechanisms of action. Endocrinology 2003;144(1):353-9.

25. Sugino T, Hasegawa Y, Kikkawa Y, Yamaura J, Yamagishi M, Kurose Y, et al. A transient ghrelin surge occurs just before feeding in a scheduled meal-fed sheep. Biochem. Biophys. Res. Commun 2002;295:255-260.

26. Thompson NM, Gill DAS, Davies R, Loveridge N, Houston PA, Robinson IC, et al. Ghrelin and Des octanoylghrelin promote adipogenesis directly in vivo by a mechanism independent of the Type 1a growth hormone secretagogue receptor. Endocrinology 2004;145(1):234-242.

27. Toshinai K, Mondal MS, Nakazato M, Date Y, Murakami N, Kojima M, Kangawa K, et al. Upregulation of ghrelin expression in the stomach upon fasting, insulin-induced hypoglycemia, and leptin administration. Biochem. Biophys. Res. Commun 2001;281:1220-1225.

28. Tschop M, Smiley DL, Heiman ML. Ghrelin induces adiposity in rodents. Nature 2000;407:908013. 
29. Ueno H, Yamaguchia H, Kangawab K, Nakazato M. Ghrelin: a gastric peptide that regulates food intake and energy homeostasis. Regulatory Peptides 2005;126:1119.

30. Wertz A, Knight T, Kreuder A, Bohan M, Beitz D. Effect of feed intake on plasma ghrelin concentration in beef cattle. Anim. Industry Report 2004.

31. Wren AM, Small CJ, Thomas EL, Abbott CR, Ghatei MA, Bell JD, et al. Continuous subcutaneous administration of ghrelin results in accumulation of adipose tissue, independent of hyperphagia or body weight gain, Endocrine Abstracts Spring 2004, 35.

32. Wu X, Tang M, Ma O, Hu X, Ji C. Effects of Exogenous Ghrelin on the Behaviors and Performance of Weanling Piglets. Asian Aust. J. Anim. Sci 2008;21(6):861-867. 